\title{
Kenevir Liflerinin Eldesi, Karakteristik Özellikleri ve Tekstil Endüstrisindeki Uygulamaları
}

\author{
Seher KAYA ${ }^{(D)}$, Eren ÖNER ${ }^{(D)}{ }^{*}$ \\ ${ }^{1}$ Uşak Üniversitesi, Mühendislik Fakültesi, Uşak \\ Geliş Tarihi (Received): 24.02.2020, Kabul Tarihi (Accepted): 07.04.2020 \\ $\square$ Sorumlu Yazar (Corresponding author*): eren.oner@usak.edu.tr \\ (C) +902762212121 且 +902762212137
}

ÖZ

Kenevir, yenilenebilir ve sürdürülebilir karakterde ve çok amaçlı bir ürün olması sebebiyle bilimsel, sektörel ve ekonomik yönlerden günden güne önem kazanan bir malzeme olmaktadır. Esasında kenevir bitkisi insanlık tarihi boyunca kullanılmış en eski lif bitkilerinden birisidir. Buna karşın kenevir üretimi, esrar eldesinde kullanılabilmesi ve zamanla sentetik liflerin yaygınlaşması sebebiyle küresel anlamda gerilemiş ve ülkemizde ise bitme noktasına gelmiştir. Tekstil, ilaç, kâğıt, biyoyakıt, kozmetik ve otomotiv gibi birçok farklı sektörde oldukça geniş bir kullanım alanı olan kenevir, petrol ve petrokimyanın kullanıldığı her alanda alternatif olan, üstün özelliklere sahip bir bitkidir. Ayrıca kenevirin, ekolojik özellikleri sebebiyle de sürdürülebilirliğe fayda sağlaması beklenmektedir. Türkiye'deki iklim şartları kenevir yetiştirmeye elverişli olduğu için yapılacak yatırımların geri dönüşünün hızlı bir şekilde gerçekleşmesi ön görülmektedir. Bu çalışmada kenevirle ilgili güncel çalışmalar araştırılmış ve öne çıkan yanları değerlendirilerek çevresel ve ekonomik anlamda ülkemiz ve dünya geleceği açısından katkılarından bahsedilmiştir.

Anahtar Kelimeler: Cannabis sativa, ekolojik tekstiller, gövde lifleri, kenevir, sürdürülebilirlik

\section{Production, Characteristics and Applications of Hemp Fibres in Textile Industry}

\begin{abstract}
Hemp is a material that gains importance day by day in scientific, sectoral and economic aspects because of its renewable, sustainable and multi-purpose character. In fact, hemp is one of the oldest fibre plants used throughout human history. In spite of that, hemp cultivation has declined globally and it has reached its end-point in our country due to its use in marijuana production and the spread of synthetic fibres over time. Hemp, which is widely used in many different sectors such as textile, pharmaceutical, paper, biofuel, cosmetics and automotive, is an alternative plant with superior properties. Besides, hemp is expected to benefit sustainability because of its ecological characteristics. It is estimated that, rapid realization of return on investment to be made because climatic conditions in Turkey are suitable for growing hemp. In this study, the current studies on hemp have been researched and their prominent aspects have been evaluated and their contribution to the future of our country and the world has been mentioned.
\end{abstract}

Keywords: Cannabis sativa, ecological textiles, bast fibres, hemp, sustainability 


\section{Giriş}

Kenevir, cannabinaceae familyasından olup odunsu ve bir yıllık bir bitkidir. Anavatanı Asya olan kenevir çeşitli yollarla tüm dünyaya yayılmıştır. Günümüzde iki alt türü bulunmaktadır. Bunlar; Cannabis sativa ve Cannabis indica'dır. Endüstriyel uygulamalar için önemli olan ve lif üretiminde kullanılan türü Cannabis sativa'dır. Diğer türünün uyuşturucu olarak kullanılabilmesi nedeniyle tüm dünyada üretimi yasaklanmıştır. Kenevir, insanlık tarihindeki yetiştirilen ilk kültür bitkilerinden birisidir (Acar ve Dönmez, 2016).

Cannabis Sativa olan tür, ilk olarak MÖ 2700'lü yıllarda Çin'de ilaç bitkisi olarak bulunmuş, MÖ 2000-2200 yıl öncesinde Asya'dan Avrupa'ya geçmiş ve bugünlere kadar ekimi yapılmıştır (Ulaş, 2018). Arkeolojik araştırmalar neticesinde MÖ 8000 yıllarına kadar uzanan kenevirden üretilen kumaş kalıntılarına rastlanmıştır. Türk yazılı kaynaklarına göre Anadolu'da kenevir yetiştiriciliğinin MÖ 1500'lü yıllarda yapıldığı bilinmektedir. Kenevir lifleri tarih boyunca tekstilde önemli bir yer edinmiş, ülke ekonomilerini biçimlendirmiştir. Hatta 20. Yüzyıla kadar dünyada tekstil ürünlerinin \%80'inin hammaddesini kenevir lifi oluşturmuştur.

20. yüzyıl başlarında, gelişen teknolojiyle beraber pamuk lifinin kullanılmaya başlanmasıyla birlikte daha ince iplikler üretilmiş, daha hafif elbiselerin üretimi mümkün olmuştur. 1930'lu yıllarla beraber çıkarılan esrar karşıtı yasalar, kenevir üretiminin büyük ölçüde azalmasına sebep olmuş, geliştirilen sentetik liflerle birlikte kenevirden elde edilen tekstiller önemini yitirmeye başlamıştır. Ülkemizde ise genel olarak bakıldığında Amasya, İzmir, Kastamonu, Kayseri, Kütahya, Samsun ve Sivas illerinde tarımı yapılmıştır (Acar ve Dönmez, 2016). Çok geniş kullanım alanı olan kenevirin, son yıllarda sadece Samsun Vezirköprü ve Kütahya'da tarımı yapılmaktadır (Ulaş, 2018).

Dünyada en yaygın kullanım alanına sahip doğal lif olan pamuk ve petrol esaslı sentetik lifler ile kıyaslandığında kenevir lifleri, tekstilde organik üretim olanağı ve öne çıkan çevreci özellikleri ile dikkat çekmektedir (Acar ve Dönmez, 2016).

\section{KENEVIR LIFLERININ YAPISI VE ÖZELLIKLERI}

Kenevir tek yıllık bir bitkidir. Bitkinin boğumlu, uzun bir sakı vardır. Lif hücreleri kabuk kısmında demetler halindedir ve her lif demetinde 30-50 lif hücresi vardır (Başer, 2002). Her bir lif hücresi 20-35 mikron arasında inceliğe sahiptir. Kenevir sakında bulunan primer lifler tekstil ürünlerinin üretiminde kullanılmaya uygundur. Primer lifler sürgen dokudan oluşmaktadır. Bitkinin büyüme aşamasında lif sayısında değişim olmamakta ancak liflerin boyu uzamaktadır. Kenevir bitkisinde lif kalınlığı gövdeden aşağı inildikçe artmaktadır. Lif uzunluklarını ise boğumlar arasındaki mesafe belirlemektedir. Parlak olan kenevir lifleri sarı-kahverengidir ve lifin enine kesiti poligonaldir (Gedik ve ark., 2010).

Lifin sahip olduğu özelliklere etki eden önemli parametrelerden birisi de olgunluktur. Bitkinin hasat edilme dönemi lif olgunluğunu belirlemektedir. Arzu edilen lif kalitesine göre hasat dönemi seçilmelidir. Olgunlaşmış sakta ince hücre duvarlarına küçük lümen eşlik eder. Lif elde etme amaçlı kenevir bitkisi hasadı Ağustos ayında ve çiçeklenme dönemi bitmeden hemen önce yapılmaktadır (Ulaş, 2018). Lif uzunluğu ortalama 40-45 mm'dir, bitkinin uzunluğuna bağlı olarak 2 metreye kadar ulaşmaktadır (Başer, 2002). Lifin bileşimindeki maddeler, lif özelliklerini ve davranışlarını etkileyeceği gibi üretim özelliklerine de etki etmektedir. Bu sebeple lifi oluşturan maddelerin iyi tanınması, uygun işlem koşullarının seçilebilmesi ve bu materyalden üretilmesi planlanan tekstil ürününün kullanım özelliklerini belirleme açısından önemlidir.

Kenevirin erkek ve dişi bitkisi bulunmaktadır ve bu bitkilerin görünümü Şekil 1'de verilmiştir. Genellikle ekilen tohumdan \%30-35 erkek bitki, \%65-70 oranında dişi bitki elde edilmektedir. Yani üretici tohumu tarlaya ekerken erkek veya dişi bitki tohumu seçip ekme seçeneğine sahip değildir (Aytaç, 2018). Cannabis Sativa (endüstriyel kenevir), ana etken maddeleri ve aroma veren maddelerle birlikte 120 adet madde içermektedir. Kenevirde dişi bitkinin tohumu etrafında yer alan yaprakları ile dişi ve erkek türlerinin çiçekli tepeleri psikoaktif maddeler içermektedir (Özşeker ve ark, 2017). Bunlardan en dikkat çekenleri, THC ( $\triangle 9$-tetrahidrokannabinol) ve $C B D$ (Cannabidiol)'dür (Ulaş, 2018). CBD, THC gibi maddeler kenevirin çiçekli bitki kısımlarında daha fazla oranda bulunur (Şekil 1) (Aytaç, 2018). Endüstriyel kenevir, THC oranı, kuru ağırlık cinsinden \% 0,2 (Avrupa Birliği), \% 0,3 (Kanada)' ün altında olan türdür. Dişi bitkilerde ise bu oran \%5-35 aralığındadır. Endüstriyel kenevirin THC oranının çok düşük, CBD oranınınsa yüksek olması istenmektedir. Toplumda esrar olarak bilinen ve yüksek narkotik madde (THC) içeren narkotik ürünler dişi kenevirden elde edilmektedir. 20. Yüzyılda petrol ürünü polyester kullanımının yaygınlaşması, bu ürünün kenevir liflerinden daha ucuz olması ve petrol ürünlerini pazarlamaya teşvik sebebiyle kenevir ekimi gittikçe azalmıştır (Ulaş, 2018). 


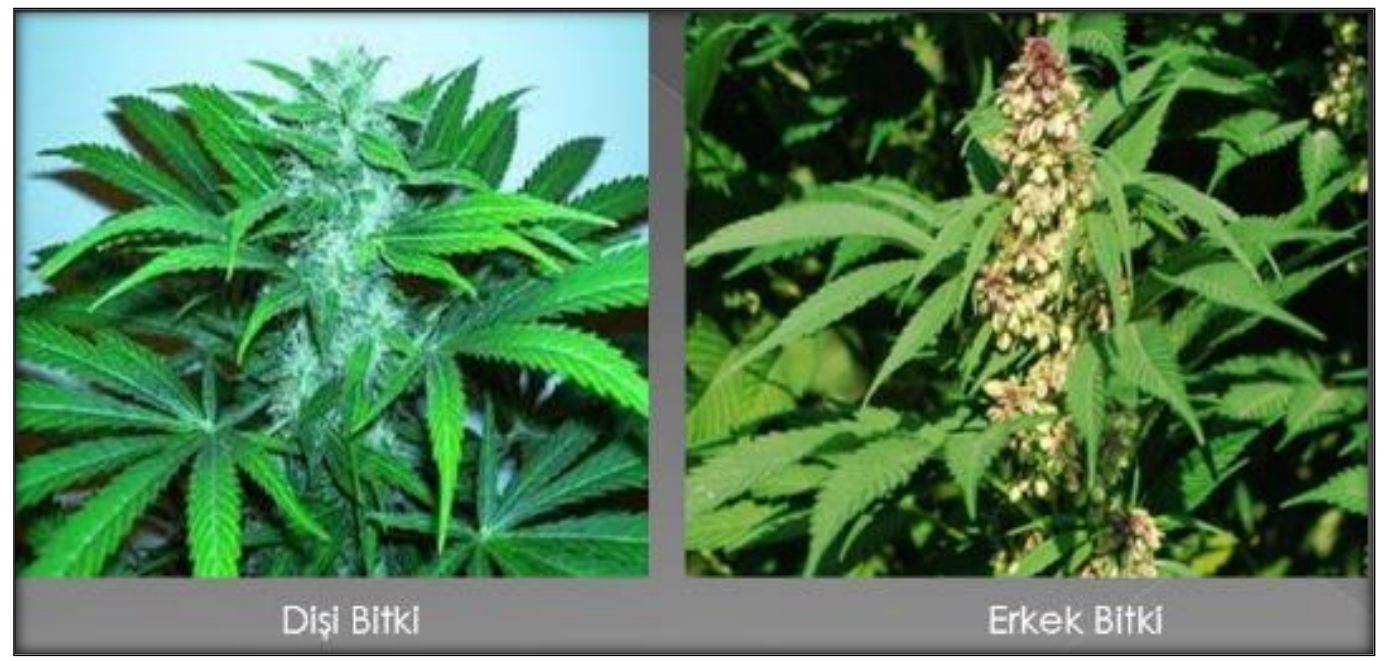

Şekil 1. Dişi ve erkek kenevirin görünümü (Aytaç, 2018).

\section{Kenevir Liflerinin Kimyasal Özellikleri}

Kenevir lifleri selülozun yanında hemiselüloz, lignin ve pektin içermektedir (Ulaş, 2018). Kimyasal bileşiminde \%78'e kadar selüloz, \%9'a kadar da lignin ve pektin bulunur (Tablo 1).

Tablo 1. Kenevir ve diğer bazı selülozik liflerin kimyasal bileşimi (Gedik ve ark., 2010).

\begin{tabular}{|l|c|c|c|c|}
\hline & \% Selüloz & \% Hemiselüloz & \% Lignin & $\%$ Pektin \\
\hline Pamuk & 92 & 6 & - & $<1$ \\
\hline Jüt & 72 & 13 & 13 & - \\
\hline Keten & 81 & 14 & 3 & 4 \\
\hline Sisal & 73 & 13 & 11 & 2 \\
\hline Kenevir & 74 & 18 & 4 & 1 \\
\hline Rami & 76 & 15 & 1 & 2 \\
\hline Kapok & 13 & - & - & - \\
\hline
\end{tabular}

Kenevir lifleri, pektin zamk ile bir araya gelen elementer liflerden oluşur. Yüksek su tutma kapasitesine sahip pektik maddeler polisakkarit türevleridir. Kenevir lifinde pektin primer duvar ve orta lamel mevcuttur. Suda çözünmez formdaki pektin, pektik asidin kalsiyum, magnezyum ve demir tuzları olarak bulunur. Kenevir liflerinde bulunan diğer bir bileşen "lignin" maddesidir. Lignin fenilpropandan türemiş ünitelerden oluşmuştur. Kısa zincirli izotropik ve kristalin olmayan yapıdadır. Lif demetlerinde orta lamelde ve odunumsu çekirdek ile epidermal ve kortikal hücrelerde bulunur. Lignin oranından dolayı elde edilen lifler, kaba lifler şeklindedir (Başer, 2002). Bu madde selülozdan sonra en çok bulunan biyopolimerdir. Aromatik ve alifatik gruplar içeren lignin, ayrıştırılması zor bir moleküldür. Enzimlere ve kimyasallara karşı oldukça dirençlidir. Toprak seviyesinin üstünde boy alan bitkilerde bulunur (Ulaş, 2018). Lignin, pektin gibi, amorfik selülozun bölümlerinde lif lignifikasyonuna katkıda bulunan mekanik kabuklanmalar yaratır. Ek olarak, lignin de sıklıkla temel lifleri birleştiren orta tabakalarda bulunur. Hem temel lifte hem de teknik lifin lifler arası tabakalarında ligninin bulunması, lifi daha sert, daha kırılabilir hale getirir, ayrılabilirliğini ve bükülebilirliğini azaltır.

Özellikle kenevirin istenmeyen bir özelliği, ikincil bir lifin varlığıdır. Bu, çoğunlukla, gövdenin alt kısmında, birincil lifle eşlik ettiği orta kısma kadar meydana gelir. İkincil lifin \% 40'ı, standartlara uygun kenevir lifi için kabul edilebilir. İkincil lif genellikle birincil liften daha kısa, daha kaIın, daha kırılgan ve eğirme için uygun değildir (Cierpucha ve ark., 2004). Bir lif içerisindeki ana bileşenlerin ve aynı zamanda lif fiziksel özelliklerinin oranı, kenevir bitkisel dönemi, yetiştirme teknolojisi, çeşitlilik ve hasatta büyüme / olgunluk aşamasındaki iklim koşullarına da 
bağlıdır (Amaducci ve Gusovius, 2010; Celino ve ark., 2014; Reddy ve Yang, 2005; Keller ve ark., 2001; Mediavilla ve ark., 2001). Kimyasal bileşim ayrıca bitki kısımları arasında da değişebilmektedir (Keller ve ark., 2001).

\section{Kenevir Liflerinin Fiziksel Özellikleri}

Kenevir, yüksek mukavemet, dayanıklıık ve emicilik sağlayan doğal bir liftir. Yıllık lif verimi oldukça yüksektir ve bu liflerden üretilen kumaşlarda boncuklanma(pilling) problemi yaşanmaz.

Kenevir $20^{\circ} \mathrm{C}$ 'de $\% 65$ bağıl nemde $\% 12$, $\% 95$ bağıl nemde ise $\% 30$ nem alır ve bu değerler pamuk ve ketenden çok daha yüksektir (Özdemir ve Tekoğlu, 2013). İyi elektrostatik özellikler, UV koruma sağlama ve anti- alerjik özellikler, bu lifin kullanımıyla tekstil malzemesine kazandırılabilecek diğer özelliklerdir (Tablo 2). Kısa lif boyuna sahip liflerle karıştırılabilmesi için yapılan pamuğa benzetme (kotonizasyon) işleminde kenevir lifleri, keten lifleri gibi kimyasal veya biyolojik işlemlerle kısa kesikli lifler haline dönüştürülür (Gedik ve ark., 2010).

Kenevir liflerinin üretiminde yüksek su tüketiminin olmaması, gübre ve tarım ilacına intiyaç duymadan yetiştirilebilmesi gibi nedenlerle toprak ve çevrenin korunmasını amaçlayan organik tarım üretimi için uygunluğunu göz önüne sermektedir. Ek olarak kenevir, ürün rotasyonuna uygun bir bitki olduğundan yabani otları yok ederek sonraki ürün için zengin bir toprak yapısı bırakmaktadır (Ulaş, 2018).

Tablo 2. Kenevir lifleriyle birlikte bazı diğer selülozik liflerin fiziksel özellikleri (Gedik ve ark., 2010).

\begin{tabular}{|l|l|c|c|c|c|c|}
\hline Lif cinsi & $\begin{array}{l}\text { Tek lif } \\
\text { uzunluğu } \\
\text { (cm) }\end{array}$ & $\begin{array}{l}\text { Isslem gör- } \\
\text { müş } \\
\text { uzunluğu } \\
\text { (cm) }\end{array}$ & $\begin{array}{l}\text { Kuru özgül } \\
\text { mukavemet } \\
\text { (cN/dtex) }\end{array}$ & $\begin{array}{l}\text { Yaş özgül mu- } \\
\text { kavemet } \\
\text { (\% kuru) }\end{array}$ & $\begin{array}{l}\text { E-modül } \\
\text { (Mpa) }\end{array}$ & $\begin{array}{l}\text { Yıllık lif verimi } \\
\text { (kg/hektar) }\end{array}$ \\
\hline Pamuk & & $1-6$ & $25-50$ & 105 & 11 & $800-1000$ \\
\hline Kenevir & $100-300$ & $65-75$ & $35-70$ & 105 & 12,7 & 3000 \\
\hline Jüt & $160-360$ & $65-75$ & $30-34$ & 100 & $19-35$ & 2200 \\
\hline Keten & $20-40$ & $10-40$ & $30-55$ & 105 & $12-26$ & 2000 \\
\hline
\end{tabular}

\section{KENEVIRDEN LIF ELDESi}

Olgunluk, endüstriyel uygulamalarda kullanılacak tekstil lifleri için belirleyici bir faktördür. Tek bir lifin olgunluk aşaması ikincil duvarın gelişmesiyle birlikte dıştan içe doğru gerçekleşmektedir. Olgun hale gelmiş sakta, hücre duvarları ince yapıdadır ve lümen ise hacim olarak küçüktür. İkincil duvardaki gelişim bitkide büyüme aşamasında başlamakta ve çiçeklenme aşamasından sonra devam etmektedir. Liflerin karakteristik özellikleri bitkinin hasat dönemine göre değişiklik göstermektedir. Bu sebeple istenen lif kalitesinde ürün elde etmek için doğru hasat döneminin seçilmesi önemlidir.

Kenevir bitkisinin hasadı sonrasında saplardan liflerin ayrılması işlemi keten lif eldesi yöntemleriyle benzerlik göstermektedir. Saplardan liflerin ayrılması işlemi için mekanik ayırma, çiğde bekletme, havuzlama, kimyasal işlem ve enzim uygulama gibi yöntemler mevcuttur. Burada yapılan işlem, saplardaki odunsu bölümlerin uzaklaştırılması ile liflerin ortaya çıkarılmasıdır (Şekil 2) (Gedik ve ark., 2010). 


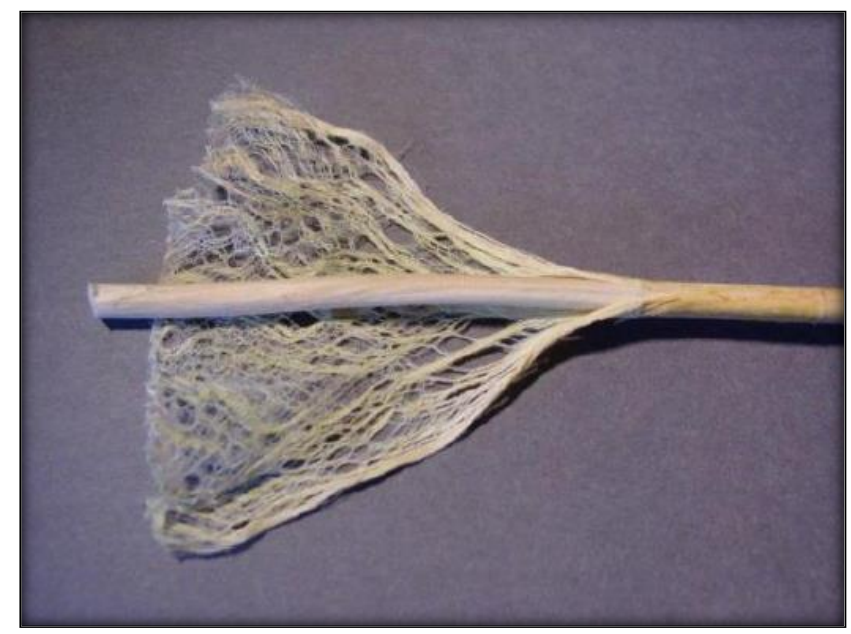

Şekil 2. Kenevir sakındaki tekstil üretimine uygun primer lifleri (Orta Doğu Kalkınma Ajansı, 2019).

Hasadı yapılan ve tohumları ayrılmış olan kenevir saplarından lif elde etmek için temelde 3 farklı yöntem uygulanmaktadır:

\section{- Biyolojik Havuzlama Yöntemi:}

Bu işlemde kenevir sapları tarlalara serilerek mikroorganizmaların etkisine bırakılır. Yüksek nem içeriğine sahip bölgelerde, ilkbahar ile sonbahar mevsimlerinde yapılan bu işlem ile sıcaklık ve rutubetin etkisiyle mantarların çoğalması kolaylaşmaktadır. En az 1,5 aylık zaman diliminde gerçekleşen bu yöntemde çürüme olayı yavaş gerçekleştiğinden, yumuşak tutuma sahip ve ince lifler elde edilmektedir (Hess, 1954).

\section{- Mekanik Yöntem:}

Kenevir bitkisinin sapları kırılıp ezilmek suretiyle lifli bölgeleri ve odunsu kısımları birbirinden ayırarak lif eldesini sağlayan yöntemdir. Bu yöntem, havuzlama yöntemiyle karşılaştırıldığında daha hızlı ve daha ekonomik bir yöntem olmasına rağmen elde edilen lifler daha sert olmaktadır. Hücreler arası pektinin mekanik yolla giderilmesi mümkün olmadığı için mekanik yöntem, tekstilde kullanılan liflerin üretimi için uygun değildir (Harmancıoğlu ve Yazıcıoğlu, 1979).

\section{- Kimyasal Yöntem:}

Kenevirden lif üretimi için uygun olan enzim metodundan sonraki en uygun yöntemdir. Saplardan ve çöplerden arınmış, temiz, eşit uzunlukta lifler elde edilir. Bu yöntemde önce kenevir sapları kesilir ve alkali banyoda belirli basınç altında pişirilir. Bol su ile yıkanıp çalkalanarak pektin maddesinden arındırılır. Sonrasında kurutulan kenevir lifleri, pamuk ve benzeri liflerle karıştırılarak iplik elde edilir. Kurutulmaya bırakılmış kenevir sakları Şekil 3'te gösterilmiştir. Ancak günümüzde, soğuk veya sıcak havuzlama yöntemleri yeniden değerlendirilmekte olup, bazı noktalarda kenevir lif üreticileri tarafından bir takım sakıncaları olduğu söylenmektedir. Çünkü havuzlama esnasında sudaki oksijen oranının fazla miktarda azalması ve işlem sonrası organik maddeler içermesi, çevre kirliliği açısından zararlı görülmektedir. Çevre kirliliğine duyarlı olan ülkeler bu unsurları göz önünde bulundurarak araştırmalarını yoğunlaştırmışlardır. Özellikle Fransa ve Hollanda, kenevirle ilgili geliştirdikleri yeni üretim yöntemlerini, tekstil ve kâğıt üretim sanayisinde uygulamaktadırlar (Herer, 1993). 


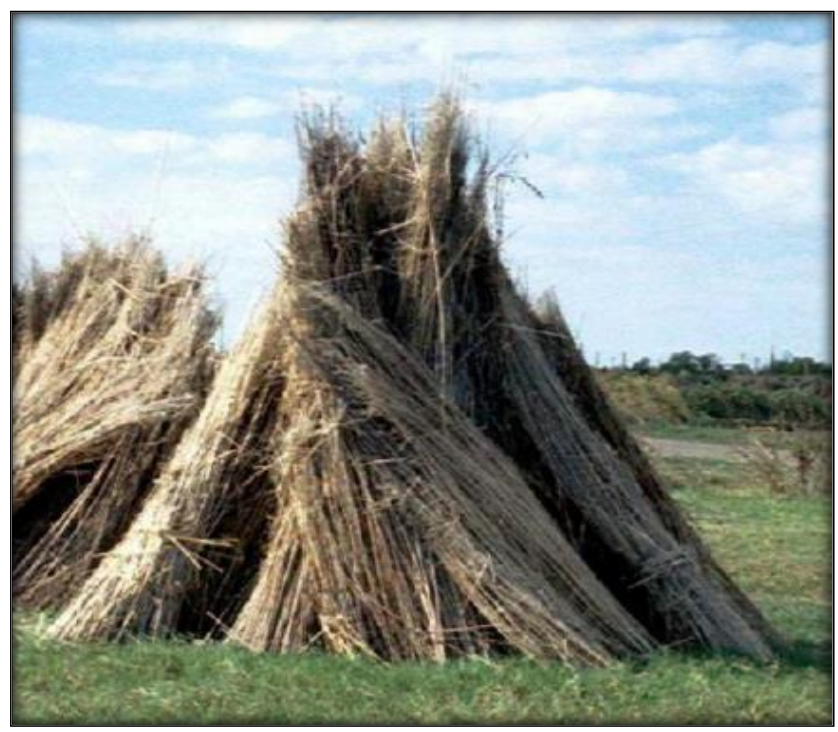

Şekil 3. Kurutulmaya bırakılmış kenevir sakları (Orta Anadolu Kalkınma Ajansı, 2019).

Kenevir yılda 2 sefer hasat edilebilmektedir. Kenevirin dişi ve erkek bitkilerinin olgunlaşma süreçlerinin değişiklik göstermesi hasat sırasında sorun oluşturmaktadır. Erkek kenevirler çiçeklenmeden hemen sonra yaklaşık olarak ekilmelerini takiben 100-110 gün sonra hasat olgunluğuna ulaşmaktadırlar. Bu aşamada saplar en yüksek lif kalitesine sahip olmaktadırlar. Erken hasat edilmeleri durumunda mukavemeti düşük lif içeriği sebebiyle lif verimi düşerken, geç yapılan hasatta ise biçilen sapların havuzlanması güçleşmektedir. Hatta böyle bir durumda saplarda selüloz yerine lignin birikmesi nedeniyle odunlaşma sonucunda hiç bir lif elde edememe durumu ile karşılaşılabilmektedir (Ulaş, 2018). Tozlaşma sonrasında da dişi ve erkek kenevir bitkileri hasat edilebilmektedir. Bu şekilde dişi bitkilerin liflerinden de yararlanmak mümkündür. Tohum eldesi amacıyla yapılacak ikinci hasatta ise tohum oluşum evresinden hemen sonra dişi ve erkek bitkilerin hasadı yapılmalıdır (Gedik ve ark., 2010).

Kenevir lifinin fiziksel ve kimyasal özellikleri ve özütlenme yöntemleri, farklı ürünlerde kullanılması önemlidir. Kenevir lifi ekstraksiyonu için çeşitli işlemler çalışımış ve uygulanmıştır. Lif demetleri, enzimatik, mikrobiyolojik, kimyasal ve fiziksel yöntemler kullanılarak ayrılabilir, ancak şimdiye kadar geliştirilen yöntemler, endüstriyel uygulamalar için ekonomik bir uygulanabilirlik göstermemektedir (Reddy ve Yang, 2005; Amaducci ve Gusovius, 2010). En yaygın kullanılanları, her ikisi de yerli mikrofloranın salgıladığı pektik enzimler tarafından gerçekleştirilen çiğ ve su tutma yöntemleridir (Mwaikambo, 2006; Bengtsson, 2009; Zhang ve ark., 2008).

Genellikle $50 \mathrm{~kg}$ kenevir sapından havuzlama işlemi sonunda $15-25 \mathrm{~kg}$ arasında kurutulmuş kenevir sapı elde edilmektedir. Kurutulmuş saplardan ise $3 \mathrm{~kg}$ uzun lif, 5-
6 kg kısa lif elde edilebilmektedir. Ülkemizde dekar başına lif verimi ortalama 150 kg'dır (Ulaş, 2018).

\section{KENEVIRIN KULLANIM ALANLARI}

Artan bilinç düzeyiyle birlikte insanlardaki ekolojik kaygıların artması sebebiyle kenevir liflerinden üretilen tekstil ürünlerine olan talep günden güne artmaktadır. Bunun yanında kenevir liflerinin fiziksel ve kimyasal yapılarından kaynaklı üstün performans ve kullanım özellikleri pazardaki müşterilerin dikkatini çekmektedir (Özdemir ve Tekoğlu, 2013). Tüm bunlara karşın kenevir lifleri günümüzde dünya doğal lif üretiminin $\% 0.5$ 'inden azını oluşturmaktadır (Shahzad, 2012).

Doğada dişisi ve erkeği gözle ayırt edilebilen tek bitki olan kenevir lifleri genel olarak dünyada sektörel bazda kullanılır (Ulaş, 2018);

- İlaç yapımında,

- Kâğıt yapımında,

- Yakıt yapımında (biyoyakıt),

- Kumaş yapımında,

- Tüm tekstil ürünlerinde,

- Otomotiv sektöründe,

- Petrol ve petrokimyanın kullanıldığı her alanda,

- Kozmetik ve sabun yapımında,

- Elektrik üretiminde,

- İnşaat sektöründe,

- Yem sanayisinde,

- Yağ yapımında,

- Asfalt ve yol yapımında

Kenevir, çeşitli kullanımlar ve endüstriyel uygulamalar için bir kaynağı temsil eden ekonomik imtiyazlı değerli bir üründür (Amaducci ve Gusovius, 2010; Salentijn ve 
ark., 2014). Global kenevir pazarının 25.000 'den fazla üründen oluştuğu (Salentijn ve ark., 2014) ve kenevir ürünlerinin yeni uygulamalarının sürekli ortaya çıktığı tahmin edilmektedir. Yaygın olarak kağıt, tekstil, inşaat, izolasyon, tarım, kompozitler, otomotiv, tıp, vb. alanlarda yaygın olarak kullanılan lifli gövdesi için yetiştirilmektedir (Fuqua ve ark., 2012; Salentijn ve ark., 2014; Delaney ve Madigan, 2014). Uzun lif yapısı sayesinde, fantezi iplik çalışmalarına, özel dokumalara, tuvallere ve özgün çalışmalara uygulanabilir (Karus ve Vogt, 2004; Mwaikambo, 2006; John ve Thomas, 2008). Kenevir lifleri için umut verici bir uygulama, düşük yoğunluklu ve iyi spesifik mekanik özelliklere bağlı olarak yalıtım ürünlerinin ve elyaf takviyeli kompozitlerin üretimidir (Müssing vd., 2005; Zimniewska vd., 2011; Celino ve ark., 2014). Verimliliği ve selüloz içeriği yüksek olduğundan kenevir, aynı zamanda enerji ve biyoyakıt üretimi için ilginç bir malzemedir (Prade ve ark., 2011; Prade ve ark., 2012; Satya ve Maiti, 2013).

Sürdürülebilirlik açısından bakıldığında kenevir liflerinin üretiminde yüksek su tüketiminin olmaması, gübre ve tarım ilacına intiyaç duymadan yetiştirilebilmesi gibi nedenlerle toprak ve çevrenin korunmasını amaçlayan organik tarım üretimi için uygunluğunu göz önüne sermektedir. Ek olarak kenevir, ürün rotasyonuna uygun bir bitki olduğundan yabani otları yok ederek sonraki ürün için zengin bir toprak yapısı bırakmaktadır (Ulaş, 2018). Dünyada endüstriyel kenevir lifleri, mukavemet, dayanıklılık, yalıtım, akustik ve ultraviyole ışınlara karşı direnç gibi farklı özellikleri ile ilginç bir sürdürülebilir malzeme olarak kabul edilmektedir (Awwad ve ark., 2012). Kenevir liflerinin zirai alanlarda potansiyel kullanımının, toprak eğimlerinin ve düzenli depolama sahası sistemlerinin onarımı için sürdürülebilir bir çözüm sağlayacağı düşünülmektedir (Najjar ve ark., 2014). Çevresel etki konusundaki büyük intiyaç ve farkındalık göz önünde bulundurularak, kenevir malzemesinin performansı ve geri dönüştürülebilirliğiyle farklı disiplinlerdeki uygulama çaIışmalarına uyumluluğu son zamanlarda mühendislik ürün tasarımında daha yüksek önceliğe sahip olmasına neden olmaktadır (Al-Oqla ve Sapuan, 2014).

Gövdesi kenevirden üretilen otomobillerin dayanıklılığı çelikten üretilenlere göre on kat daha fazla olmaktadır. 20.yy. başlarında, kenevirden türetilen selüloz, plastiklere yönelik yenilenebilir hammadde haline getirilmiştir. 1930'larda Henry Ford, kenevir liflerini kullanarak, biyolojik alaşım maddelerinden, bir araba prototipi geliştirmiştir. Reklamı yapılıp, dayanıklılık özelliği ön plana çıkarılan bu araçlar, politikalar gereği seri üretime geçirilememiştir. Şekil 4'te kenevirden üretilen Ford marka aracın tanıtımı gösterilmektedir (Ulaş, 2018).

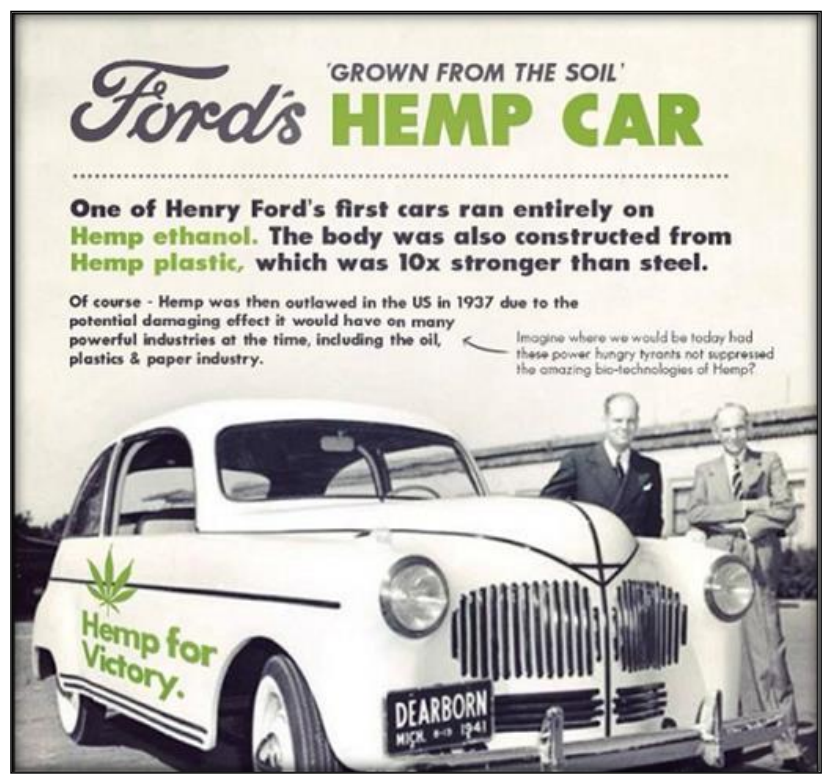

Şekil 4. Ford'un kenevir kullanarak geliştirmiş olduğu araç (Ulaş, 2018).

Kenevirden iplik ve kumaş üretimi için kaliteli liflerin eldesi, yüksek işlem maliyetleri sebebiyle Batı Avrupa'da son yıllarda sadece laboratuvar ortamında başarılabilmiştir. Macaristan, Romanya, Ukrayna ve Polonya'daki kenevir işleme endüstrisi, lif eldesini temel olarak havuzlama süreçleriyle devam etmeyi sürdürmüştür (Dreyer ve ark., 2002). 


\section{DÜNYADA VE ÜLKEMIZDE ENDÜSTRIYYEL KENEVIR}

Amerika Birleşik Devletleri narkotik özellikleri sebebiyle uzun yıllardır endüstriyel kenevirin yaygınlaşmasına, endüstride daha etkin kullanılmasına ülke politikası olarak karşı çıkmıştır. Kanada, 1994 yılında aralarında kenevirinde bulunduğu araştırma bitkilerini lisanslamaya başlamıştır. Fransa, keneviri hiçbir zaman yasaklamamıştır. Fransa, günümüzde diğer ülkeler için düşük THC üreten kenevir tohumlarının kaynağı durumundadır. Almanya, 1982 'de keneviri yasaklamış ancak 1992'de yeniden araştırmaları başlatmış ve yasaklar Kasım 1995'te kaldırıldıktan sonra, birçok teknoloji ve ürün geliştirmeye devam etmiştir. Mercedes ve BMW kapı panelleri, gösterge panoları vb. kompozitler için kenevir lifini kullanmaktadır. Çin, kenevir tekstilinin en büyük ihracatçısı konumundadır. Çin'de 2017 yılında yaklaşık 50 bin hektar endüstriyel kenevir ekilmiştir. 10'dan fazla enstitü ve kurum, endüstriyel kenevir alanında AR-GE çalışmaları yapmaktadır. Çin, günümüzde küresel kenevir üretiminin $\% 50$ 'sinden fazlasını ve tekstil endüstrisine yönelik kenevir lifi kullanımı üzerine 600'ün üzerinde uluslararası patente sahiptir. Bu ülkelerin yanında Şili, Polonya, Romanya, Macaristan, Avustralya, Avusturya, Hindistan, Hollanda, İspanya, Yeni Zelanda, Rusya, İtalya, İsviçre, Danimarka ve Finlandiya'da da kenevirle ilgili çeşitli tarım ve lisanslama faaliyetleri yapılmaktadır (Şekil 5) (Ulaş, 2018).

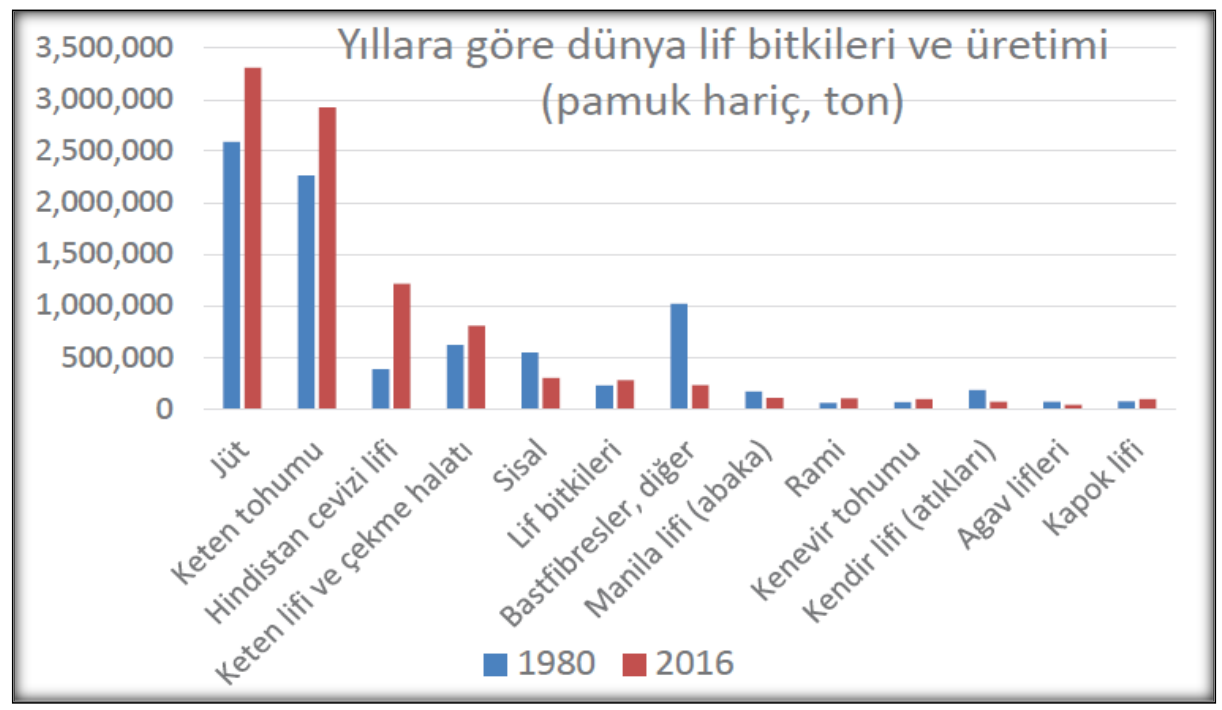

Şekil 5.Yıllara göre dünya lif bitkileri ve üretimi (Ulaş, 2018).

14 Eylül 2000 yılında BioresourceHemp2000 konferansıyla, Avrupa Endüstriyel Kenevir Derneği (EIHA) Almanya'nın Wolfsburg kentinde kurulmuştur. Avrupa Endüstriyel Kenevir Derneği, Avrupa Birliği üyesi ülkelerin kenevir üzerine faaliyette bulunan firmalarını bir araya getirerek kenevir konusunda ortak hareket etmeyi, bilgi paylaşımını ve gelişmeleri değerlendirmeyi amaçlamaktadır (European Industrial Hemp Association-EIHA, 2019). Bununla birlikte $A B$ 'de rekabetçi, yenilikçi ve sürdürülebilir bir kenevir endüstrisinin gelişmesini teşvik etmek amacıyla HEMP-SYS projesi hayata geçirilmiştir. Bu proje tüm kenevir üretim zinciri boyunca iyileştirmeler ve kalite standartlarını araştırmak, geliştirmek ve uygulamak için tasarlanmıştır (Amaducci, 2003).
Türkiye'de kenevirin 1971 yılı sonrasında başlayan duraklaması, 1990 yılında alınan ilk karar ve yönetmelikle kontrollü olarak yetiştiriciliğine izin verilerek biraz hareketlenmiş olsa da ancak bilinç düzeyi düşük olduğundan ticarileşememiş ve bitkinin üretimi bitme noktasına gelmiştir. Toprak Mahsulleri Ofisi Genel Müdürlüğü verilerine göre, 1988 yılında 1200 ton olan kenevir tohum üretimi, 2013 yılında 1 tona düşmüş ve son 5 yıldır da 1 tonun altında yıllık üretim miktarları ile seyretmektedir. 2018 yılına gelindiğinde ise açıklanan 2017 yılı verilerine göre ülkemiz genelinde sadece $950 \mathrm{~kg}$ kenevir tohumu üretilmiştir (Şekil 6). 


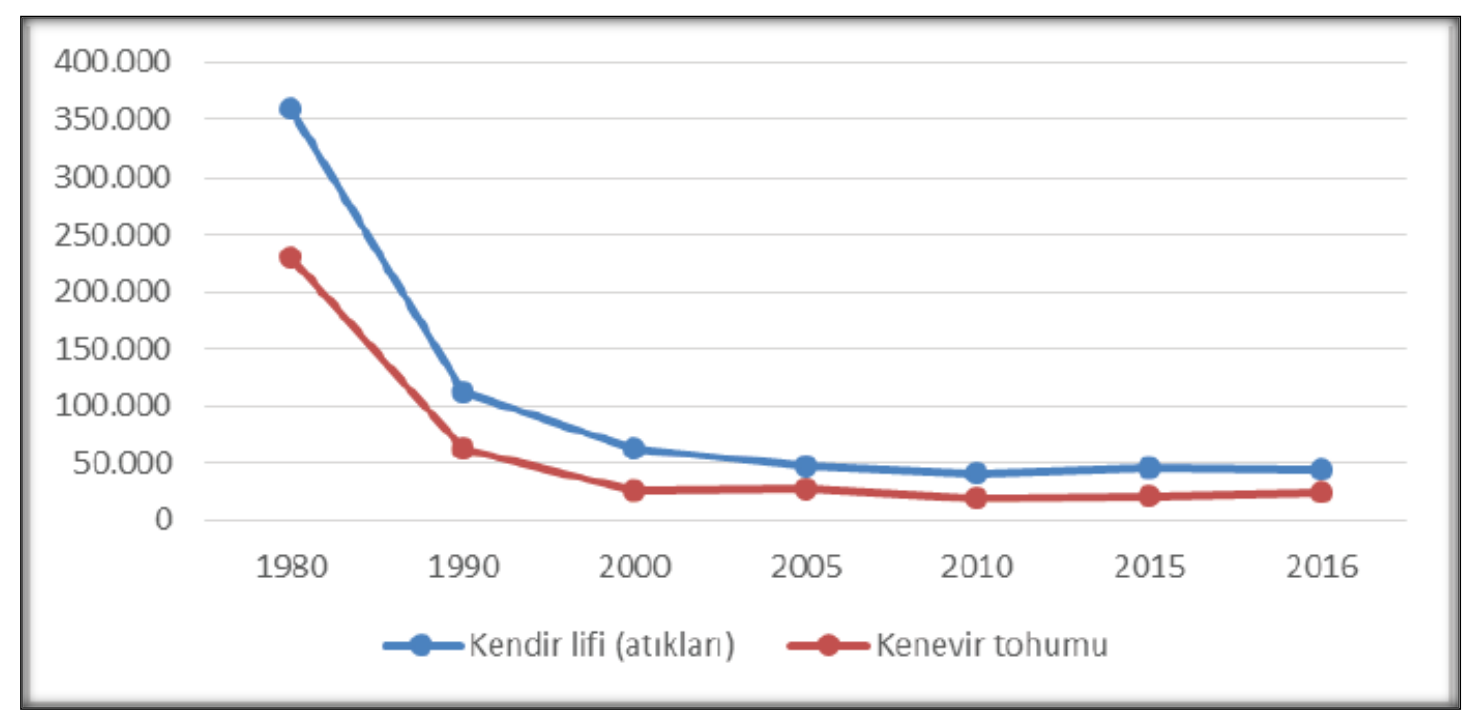

Şekil 6. Türkiye'de yıllar itibarıyla kenevir lifi ve tohum üretimi (Ulaş, 2018).

Dünyada 2017 yılında 2 milyon tonun üzerinde kenevir tohumu üretimi yapılmıştır. Avrupa Endüstriyel Kenevir Organizasyonu'nun (EIHA) tahminleri doğrultusunda 2025 'e kadar kenevirin odunsu kısmı ve tozunun 60 kat, kenevir lifi ile güçlendirilmiş biyokompozitlerin 4 kat, Kenevir tohumu ve gıda pazarının 60 kat artacağı; hayvansal yatak malzemelerinin 3 kat, kenevirden kâğıt üretiminin 20 kat artacağı öngörülmektedir. Avrupa ülkelerinde kenevir ekimi 2002'den 2017 sonuna kadar yaklaşık 90.000 hektara ulaşmıştır. Ülkemizde bu rakam 100 dekarın altındadır (Ulaş, 2018).

\section{KENEVIR İLE İLGILI LITERATÜRDEKI GÜNCEL ÇA- LIŞMALAR}

Keller ve ark. (2001), kabuğun ve kovanların boyanmamış endüstriyel kenevirden (çeşitlilikteki 'Kompolti') mümkün olduğunca az lif hasarı ile ayrılabileceği büyüme aşamasını belirlemek üzerine araştırma yapmıştır. Ayrıca çalışma kapsamında, kabuğun kimyasal bileşimi ve lif selülozun molekül ağırlığı, bir pişirme işleminden sonra elde edilebilecek lif kalitesini tahmin etmek için analiz edilmiştir. Bunun için, lifler standart bir kimyasal temizleme işlemi ile ekstre edilmiştir. Araştırmalar, bitkisel aşamalardan yaşlanmaya kadar uzanan bitkilerin dokuz büyüme aşamasında gerçekleştirilmiştir. Yeşil kuru sapların sadece kabuklarının mekanik olarak modifikasyonu dikkate alındığında, sonuçlar, tohum olgunluğunun başlangıcındaki bir hasat süresinin, kabuğun gerilme mukavemeti üzerinde herhangi bir etki olmadan kolay modifikasyon işlemine yol açtığını ortaya koymuştur. Bir sonraki temizleme işlemi de dâhil olmak üzere taze gövdelerin modifikasyonu için, erkek bitkilerin çiçeklenmesinden sonra bir hasat, modifikasyon sırasında lif kayıplarına ve azalmış inceliğe sahip liflere neden olmaktadır.
Kozlowski ve ark. (2002) tarafından yapılan çalışma, yanıcılığı sınırlı doğal lif içeren dokusuz yüzey kumaşların geliştirilmesini amaçlamaktadır. Doğal Elyaf Enstitüsü'nde (Poznan, Polonya) yapılan çalışmalarda geri kazanılmış sentetik, yün, kenevir ve keten lifleri içeriği arttırılmış, yanmaya karşı dayanıklılık gösteren dokusuz yüzey kumaşlar üretilmiştir. Sonuçlara bakıldığında, kenevir lifleri kullanılarak üretilen dokusuz yüzey malzemelerin, ateşe dayanıklılığı artmış, mobilya ve araba koltukları için döşeme sistemlerinde ve ekolojik yönlerin çok önemli olduğu yataklarda değerli ve etkili bariyer malzemeleri olarak kullanılabileceği varsayımları doğrulanmıştır.

Hautala ve ark. (2004) çalışmasında, kenevir lifi şeritlerinden ve epoksi reçinesinden kontrplak tipi kompozitler üretilmiştir. Üretilen kompozitlerin eğilme direnci sonuçları, geleneksel kontrplaklarla benzer değerlerde bulunmuştur. Görünüm, üretim özellikleri ve işlenebilirlik açısından değerlendirildiğinde ise üretilen kompozitlerin yer ve mobilya uygulamaları için uygun olduğu belirtilmiştir.

Aziz ve Ansell (2004), işlenmemiş ve alkali işlem görmüş kenevir ve kenevir lifi takviyeli polyester kompozitlerin mekanik özelliklerini araştırmıştır. Her iki kompozit tipindeki alkali ile muamele edilmiş lifler, muamele edilmemiş liflere göre üstün eğilme direnci ve eğilme modülü değerleri göstermiştir. Ayrıca, doğal lifler için özel olarak formüle edilmiş polyester reçineleri kullanmanın etkisi de incelenmiştir. Bu polyesterlerin, kompozitlerin kuvvetine olumlu bir etki yaptığı görülmüştür.

Oujai ve ark. (2004) çalışmasında, kenevir liflerinin yüzey özellikleri ve kenevir liflerinin mekanik özellikleri üzerindeki solvent ekstraksiyonu, alkalizasyonu ve akrilonit- 
ril (AN) aşılamalarının etkisini araştırmışlardır. Spektroskopik çalışmalar ve kırınım teknikleri, kristallik indeksinde hafif bir azalma göstermiştir. Liflerin selüloz 1'den selüloz 2'ye yapısal dönüşümü, ağırlıkça \% 10-\% 20 yüksek $\mathrm{NaOH}$ konsantrasyonunda gözlenmiştir. Akrilonitrille aşılanmış liflerin, merserizasyondan sonra kristal yapı dönüşümü gözlemlenmemiş, sadece aşılama miktarına sahip bir X-ışını kristalliklik endeksi varyasyonu gözlemlenmiştir. Ön işlemden geçirilmiş ve değiştirilmiş liflerin nem geri kazanımı, liflerin yapısına ve aşılama miktarına bağlı olarak değiştiği belirtilmiştir.

Tserki ve ark. (2005) çalışmasında, düşük maliyetli, tamamen biyolojik olarak parçalanabilen kompozitler üretmek için çözücü içermeyen ve katalizörsüz yapılan anhidrit muamelesinin, farklı lignoselülozik malzemeler üzerindeki etkisini araştırmışlardır. Özellikle, üç lignoselülozik malzemeler olan keten, kenevir ve odun liflerinin esterleştirilmesi, kristallik ve yüzey morfolojisi gibi özelliklere etkisi X-ışını Difraktometresi (XRD), X-ışını fotoelektron spektroskopisi (XPS), Fourier-transform kızılötesi spektroskopisi (FTIR) ve taramalı elektron mikroskobu (SEM)yöntemleri ile incelenmiştir. Liflerin kimyasal bileşimi belirlenmiştir ve ester içeriğinin, liflerin hemiselüloz/lignin içeriğine bağlı olduğu saptanmıştır. XPS ve FTIR deneyleri, muamele edilmiş lifler için lif bileşenleri ile bir ester bağında yer alan asetil/propiyonil gruplarının varlığını ortaya koymuştur. SEM incelemesi, esterleştirilmiş malzemelerin yüzeylerinin işlenmemiş malzemeden daha pürüzsüz olduğunu göstermiştir.

Turunen ve Werf (2007) çalışmasında, yaşam döngüsü analizi (LCA) metodolojisini kullanarak kenevir ipliği üretimi ile ilişkili ana etkileri ölçmeyi ve kenevir ipliğinin keten ve pamuk ipliği ile olan etkilerini karşılaştırmayı amaçlamışlardır. Kenevir bitkisi üretiminin etkilerinin değerlendirilmesi için Macaristan ve Fransa'daki kenevir üretim uygulamalarına dayanan genel bir Avrupa-Avrupa senaryosu çizilmiştir. Keten bitkisinin senaryosu ise Fransa, Belçika ve Hollanda'daki üretim uygulamalarına dayandırılmıştır. Kenevir lifi işlenmesi için, Macaristan'daki mevcut üretim uygulamalarına göre geleneksel llık suda havuzlama sistemi referans olarak kabul edilmiştir. Üç senaryo bu referansla karşılaştırılmıştır:

- Bio-havuzlama: kenevir bitkisinin yeşil haldeyken ayıklanması ve ardından seçilen bakteri türüyle suda havuzlama,

- Önceden olgunlaştırılmış kenevirin kurutulması ve bekletilmesi esasına dayanan BabyHemp,

- Ketenlerin çiğde bekletilmesi.

Biyo-havuzlamanın, lif işleme aşamasında yüksek enerji kullanımı nedeniyle iklim değişikliği ve enerji kullanımı için referans senaryodan daha yüksek etkilere sahip ol- duğu, BabyHemp'in, ötrofikasyon, arazi işgali (düşük verim nedeniyle) ve böcek ilacı kullanımı nedeniyle referans senaryodan daha yüksek etkilere sahip olduğu gözlemlenmiştir. Pamukla karşılaştırmada, karşılaştırılabilir verilerin bulunmamasından dolayı zorlanılmıştır, ancak kenevir bitkisinin üretim aşaması, pestisit ve su kullanımı bakımından pamuktan açıkça daha iyi performans gösterdiği saptanmıştır. Bu çalışmada, yaşam döngüsünün ilk üç ana aşamasından olan iplik üretim zincirine odaklanılmıştır. Bu zincirdeki ilk aşama, mahsul üretimidir. Lif işleme aşamasında lifler gövdeden çıkarılır ve iplik ve ardından kumaş üretimi için ham maddeye dönüştürülür. Pek çok alternatif üretim tekniği ve yöntemi bulunmaktadır ancak daha ayrıntılı şekilde incelendiğinde kenevir için standart bir tekstil üretim zinciri mevcut değildir. Lif işleme aşaması, kenevir tekstil üretim zincirinin darboğazıdır. Günümüzde kenevirin geleneksel lif işleme süreci, 50 yıl önceki teknolojik aşamadadır. Bu teknoloji yoğun emek gerektirdiğinden, yalnızca düşük işgücü maliyeti olan ülkeler için uygun görülmektedir (örneğin, Macaristan, Romanya, Çin). Batı-Avrupa içinse hala optimum bir işleme yöntemi bulunmamaktadır. Tekstilde tişört üretimi ve analizi daha karmaşık bulunduğundan yaşam döngü analizi sadece iplik üretiminde sonlandırılmıştır. Kenevir ipliği üretimi ile ilgili çevresel etkilerin azaltılması, lif işleme ve iplik üretim aşamalarında enerji kullanımının azaltılması ve mahsul üretim aşamasında ötrofikasyonun azaltılmasına öncelik verilmesi gerektiği öngörülmüştür. Toplam lif miktarının yarısından daha azının uzun lif olarak geri kazanıldığı görülmüştür, bu sebeple uzun lif eldesini arttırmak için çalışmalar yapılması gerektiği belirtilmiştir.

Kostic ve ark. (2008), farklı konsantrasyonlarda alkalileşmenin, farklı sıcaklıklarda kenevir lifleri üzerindeki etkisini incelemiştir. Kenevir lifleri, oda ve kaynama sıcaklığında, farklı zaman dilimlerinde ve hem gerilim hem de durgun halde sodyum hidroksit çözeltileri ile muamele edilmiştir. Liflerin kalitesi, kimyasal bileşimlerinin, inceliklerinin, mekanik ve emme özelliklerinin belirlenmesi için lifler karakterize edilmiştir. Çalışma sonunda, modifiye edilmiş kenevir lifleri inceltilmiş, liflerin lignin içeriği düşürülmüş, esneklikleri arttırılmış ve bazı durumlarda gerilme özellikleri geliştirilmiş ve gerilme özelliklerinin değerlendirilmesi için orijinal bir yöntem geliştirilmiştir. Bu yöntem, liflerin çekme dayanımı veya mukavemetinin, saplar arasındaki sıfır mesafeye kadar ekstrapolasyon değerleri kullanılarak düz bir demet olarak belirlenmesini kapsamaktadır (sıfır test uzunluğu). Sıfır test uzunluğuna ekstrapoze edilen yassı demet mukavemeti için elde edilen değerler, tek liflerde ölçülen değerlerle yüksek korelasyon gösterir ve çok daha az zaman ve beceri gerektirir. Bu yöntemin, çevre etkilerinin belirlenmesi ve lif mukavemeti üzerinde işlem yapılması için araştırma çalışmalarında ve bu lif özellikleri, işlem koşul- 
ları ve son ürün kalitesi arasındaki ilişkilerin araştırılmasında faydalı olabileceği ve ticari gönderilerin test edilmesi için kullanılabileceği öngörülmüştür. Genel olarak, alkali muamelesi, \%18 NaOH ile gerilim altında, modifiye edilmiş liflerin yüksek esneklik elde edilebilirliğini sağlamıştır. Bazı iyileştirmelerde esneklikteki değişiklikler, kimyasal bileşimdeki (ligninin ve diğer selülozik olmayan maddelerin kısmen parçalanması) ve yapıdaki (fibrillerin yeniden düzenlenmesi) değişiklikleri yansıtmaktadır. Alkali ile modifiye edilmiş kenevirin su tutma değerleri, kolay erişilebilir selülozik olmayan su emici ve tutma malzemelerinin çıkarıımasının ve lif yapısındaki değişimin bir sonucu olarak, muamele edilmemiş liflerin değerinden daha düşük olduğu belirlenmiştir.

Zhang ve ark. (2008)'nın çalışmaları, deniz suyunda havuzlama işleminin iyi derecede havuzlama sonuçları verdiğini göstermiştir ayrıca kenevirden yüksek kaliteli lifleri çıkarmak ve tatlı su tüketimini azaltmak için havuzlama işlemine olası bir alternatif olarak sunulmuştur. Deniz suyunda havuzlama, tanklardan izole edilen üç pektinolitik suş (aynı tip genotipe sahip hücrelerden oluşan bireyler topluluğu), yüksek bir pektinaz aktivitesi sergilemiştir ve iyi havuzlama performansına sahiptir. FTIR ve kimyasal analizlere göre, pektin ve hemiselüloz içerikleri, deniz suyuyla havuzlanmış liflerde, ham kenevir lifine göre daha düşük oranda bulunmuştur. Ayrıca SEM, kenevir liflerindeki selülozik olmayan sakızlı malzemelerin, deniz suyunda havuzlama işlemiyle büyük ölçüde giderilebileceğini ortaya koymuştur.

Stankovic (2008) tarafından yapılan çalışmada, yeni tasarlanan kenevir/filament hibrit iplikler, hibrit ipliklerin iç yapısının giyim tekstil malzemelerinin sıkıştırma davranışları üzerindeki etkisini araştırmak amacıyla örme kumaşlar üretmek için kullanılmıştır. Örme kumaşlar art arda sıkıştırma salma döngülerine tabi tutularak elde edilen sıkıştırma salma eğrileri, geri kazanılabilir ve geri dönüşümsüz sıkıştırma gibi belirli sıkıştırma parametrelerinin hesaplanması mümkün kılınmıştır. Parametreler kullanılarak elastik olmayan deformasyon bileşenleri (viskoelastik ve plastik deformasyon) belirlenmiştir.

Stankovic ve ark. (2008) tarafından yapılan çalışmada, kenevir, pamuk ve viskoz içerikli örme kumaşların ISI transfer özellikleri araştırılmıştır. Bu amaçla kenevir, pamuk ve viskoz liflerinden tek başına ve karışımlarıyla üretilen süprem örgüye sahip örme kumaşların kumaş gözenekliliği, hava geçirgenliği, termal iletkenlik, termal direnç gibi özellikleri incelenmiştir. Yapılan deneyler sonucunda en yüksek hava geçirgenliği ve en düşük termal iletkenlik değerleri \%100 kenevir kumaşlarda elde edilirken, en düşük hava geçirgenliği ve en yüksek termal direnç değerleri \%100 pamuk kumaşlarda elde edilmiştir. Kenevir/Pamuk ve Kenevir/Viskon karışımlı kumaşlar ise ara değerler göstermiştir.
Ariyakuare (2010) yaptığı araştırmada, atık kozalardan elde ettiği lifleri pamuk, keten, ananas, rami ve kenevir lifleri ile birlikte kullanarak iplik elde etmiş ve bu iplikleri ev tekstiline uygun kumaş yapısında kullanarak performans özelliklerini incelemiştir. Atkı ipliği olarak kullanılan atık kozadan elde edilen yeni karışık lifin ve endüstriyel dokumada çözgü ipliği olarak kullanılan beş çeşit bitki lifinin test sonucu, kenevir ipliği ile karıştırıımış atık kozadan elde edilen lifin $194 \mathrm{cN} /$ tex ile en iyi kopma mukavemetine sahip olduğunu göstermiştir. Araştırma sonuçları, kenevir ipliği ile karıştırılmış atık kozadan elde edilen lifin, en yüksek kopma mukavemetine sahip olduğundan ev tekstili üretmek için uygun olduğunu, ananas ipliği ile karıştırımış atık kozadan elde edilen lifin giysi üretmek için uygun olduğunu göstermiştir.

Miranda (2011) yaptığı çalışmada, ev tekstilinde kullanılabilecek kenevir ve pamuklu kumaşları analiz etmiş ve karşılaştırmıştır. Farklı örgülere sahip $\% 100$ pamuk ve \%100 kenevir dokuma kumaşların, sürtünmeye karşı renk haslığı, ışığa karşı renk haslığı, kir iticilik, suya karşı renk hası̆ı̆ı, güç tutuşurluk, aşınma direnci, yırtılma mukavemeti, kopma mukavemeti ve uzama açısından performans özelliklerini karşılaştırmıştır. Elde edilen sonuçlara göre, kenevir kumaşların birçok parametre açısından pamuklu kumaşlarla karşılaştırılabilir ve üstün olduğunu göstermiştir. Bu sonuçlara göre kenevir kumaşların döşemelik kumaş olarak pamuklu kumaşların kullanıldığı birçok üründe kullanılabilir bir seçenek olduğu belirtilmiştir.

Shahzad (2011)'nin çalışması kapsamında kenevir lifi kullanımıyla matris arayüzey yapışmasını iyileştirdiği ve böylece mekanik özelliklerin iyileşmesiyle çeşitli lif yüzey özelliklerinin geliştiği gösterilmiştir. Çalışmada kenevir liflerinin, cam elyaflarının kompozit malzemelerde takviye olarak kullanılması için uygun bir malzeme olmasını sağlayan özelliklere sahip olduğu belirtilmiştir. Başlıca dezavantajlarının ise, özelliklerindeki değişkenlik olduğu belirtilmiştir.

Quiguang ve ark. (2011) çalışmasında, farklı karışım oranlarına ve üretim parametrelerine sahip kenevir pamuk karışımlı penye vortex ipliklerinin üretim parametreleri araştırmışlardır. Kenevir liflerine mekanik olarak ön işlem uygulanıp yumuşatılmaları sağlanmıştır. Elde edilen bulgulara göre optimum üretimin $\% 40$ pamuk - $\% 60$ kenevir karışımıyla 21,6 tex iplik numarasında sağlandığı belirtilmiştir. Çalışmada ayrıca kenevir içerikli ipliklerin mukavemet, uzama, düzgünsüzlük özellikleri için hala geliştirilmeye açık yanlar bulunduğu ve üretim maliyetlerinin düşürülmesi, ürün geliştirme çalışmalarının yapılması ve üretim verimliğinin sağlanması konularında araştırmalar yapılması gerektiği belirtilmiştir. 
Zhihai (2011) pamuk, kenevir ve bambu liflerinin harmanlanarak iplik eğrilebilmesine yönelik üretim bandında araştırma yapmıştır. Kenevir lifleri ön işlemden geçirilmiş, lifler yumuşatıcı ile muamele edilerek üretim şartlarında 24 saat kondisyonlanmıştır. Çalışmada harman beslenmesi kontrollü olarak yapılmış tarak efekti artırılarak döküntü oranları artırılmış, ortalama lif uzunluklarına ekartman mesafeleri ayarlanmıştır. Çalışma sonunda \% 50 pamuk - \%25 kenevir - \%25 bambu oranlarında harmanlanarak 29.2 tex incelikte ipliklerin eğrilmesi sağlanmıştır. Pamuk/kenevir/bambudan harmanlanmış ipliklerin kalite talebinin karşılanabilmesi için sadece kenevir lifinin özellikleri göz önünde bulundurularak, her üretim aşamasında teknolojik önlemler alınması gerektiği belirtilmiştir.

Merdan ve ark. (2012) tarafından yapılan çalışmada, işlem görmüş kenevir liflerinin kopma dayanımı ve kopma uzaması değerleri, mikrodalga yöntemiyle araştırılmıştır. $\mathrm{Bu}$ çalışmada kenevir lifleri, farklı konsantrasyonlarda maleik anhidrit ile konvansiyonel ve mikrodalga yöntemleri kullanılarak işleme tabi tutulmuştur. İşlem görmemiş olan kenevir liflerinin kopma mukavemeti ve kopma uzaması değerleriyle, mikrodalga yöntemi sonucunda elde edilen değerler karşılaştırıldığı zaman, işlem görmemiş lifin değerlerine göre uzama değerlerinde, konvansiyonel yönteme göre kaybın daha az olduğu gözlemlenmiş, süre kısalmaya devam ettikçe uzama değerlerinde artış olduğu görülmüştür. Kenevir lifi yüzey işlemlerinde mikrodalga enerji kullanımı kısa sürede kimyasal maddeden optimum yararlanmayı, kullanılan su ve enerji miktarının daha az olmasını sağladığı belirtilmiştir.

Hwang ve Ji (2012) tarafından yapılan çalışmada, iplik numarasının ve sıvı amonyak (L/A) muamelesinin kristal yapı, buruşukluk, kuruma oranı, yıkama çekmesi, fitilleme hızı, UV koruması ve ince numara kenevir iplikler ile dokunmuş kumaşların SEM morfolojileri gibi fiziksel özellikler üzerindeki etkileri araştırılmıştır. Deneyde kullanılan çözgü ve atkı sayıları eşit \%100 kenevir dokuma kumaşlar, Nm 24, 36, 48 ve 60 incelikteki ipliklerden dokunmuştur. Kumaşlar, sıvı amonyak içinde 2 saniye boyunca, gerilimsiz koşullar altında $-33.4^{\circ} \mathrm{C}$ ' de işleme tabi tutulmuştur. L / A işleminin bir sonucu olarak, kenevir lifi kristal yapısı selüloz I' den, selüloz III ve selüloz I karışımlarına değiştirilmiş ve kristalliliği \% 13 oranında hafifçe azaltılmıştır. L/A ile işlem görmüş kenevir kumaşının kırışık geri kazanımı \% 78'e kadar iyileştirilmiş, kumaşın yıkama çekmesi \% 0,4'ün altına düşerken, ince numara iplikle hazırlanan kenevir kumaşın yıkama çekmesinin, kaba iplikle hazırlanan kenevir kumaştan daha iyi değerlere sahip olduğu gözlemlenmiştir. Özellikle işlem görmüş kenevir kumaşlarının fitilleme hızı ve kuruma oranı, iplik numarası arttıkça işlemden geçirilmiş olanlardan daha yüksek olduğu görülmüş ancak bu işlemin UV korumasında önemli bir etkisinin olmadığı bulunmuştur.

Fuqua ve ark. (2012)'nin çalışmasında biyo-bazlı liflerin kompozit takviye materyali olarak kullanımı araştııılmıştır. Bu liflerin ara yüzünü arttırmak için kullanılan yöntemler çeşitli polimer matrislerle incelenmiştir. Tekstil işlemlerinin, takviye yeteneğine sahip çeşitli lif yapıları yaratma üzerindeki etkisi, doğal lif takviyeli kompozitlerin işlenebilme yöntemleri ele alınmış, ayrıca yapı, işleme ve son bileşik özellikler arasındaki korelasyon belirlenmesi sağlanmıştır.

Marrot ve ark. (2013)'nin araştırmalarının amacı nispeten zayıf kenevir lifi mekanik özelliklerinin kaynağını ve neden dağıldıklarını daha iyi anlamaktır. Bu araştırmayla kenevir sapı, nano girinti, lif morfolojisinin analizi ve son olarak lif biyokimyasal kompozisyonu ile mekanik performansları arasındaki ilişkinin incelenmesi yoluyla özgün bir çalışma önerilmiştir. Çalışmada, liflerin morfolojileri analiz edilmiş; elektronik ve optik mikroskop kullanılarak aynı kenevir kök bölümlerinin ince kesimleri gözlenmiştir. Lif sertliği yayılımının kökeninin araştırılması için, kenevir gövdeleri üzerinde nanoiz testi(nanoindentation) kullanılarak rijitlik ölçümleri yapılmıştır ve lif kenevirin kristallenmesinin X-ışını difraksiyonu (XRD) analizi yapılmıştır. Kenevir mekanik özelliklerini vurgulamak ve bunları literatür verileriyle karşılaştırmak için manuel olarak çıkarılan tek kenevir lifleri üzerinde çekme testleri yapılmıştır. Bu çalışmada, kenevir liflerinin incelenmesinde kullanılan (Fedora 17 çeşidi), bu bitki liflerinin, keten liflerine kıyasla, değişken ve zayıf mekanik özellikler gösterdiğini sergilemiştir. Bu mekanik davranışı açıklamak için çeşitli iç parametreler araştırılmıştır. Enine kesitte bulundukları yere göre lif ve lümen morfolojisindeki güçlü farklılıklar vurgulanmıştır ve muhtemelen bu farklılıkların sebebi, hesaplanan gerilme özelliklerindeki kayda değer dağılımdır. Yapılan nanoiz testleri neticesinde, çalışmada havuzlanmamış kenevirin kullanıldığı ve bu sebeple modifikasyonun daha da zorlaştığını gösteren yüksek odunlaşma ve güçlü orta lameller fark edebilir. Ayrıca kompozit takviye için, doğru bir uygulamada tanımlanan her bir sak, gerekli spesifikasyonları gerçekleştirebilir, doğru bir havuzlama kullanılarak kenevir performansları arttırılabilir. Nitekim suda veya çiğde havuzlama işlemi, orta lamellerde bulunan bazı pektin ve ligninlerin ortadan kaldırılmasını mümkün kılar. Defibrasyonu kolaylaştıır, böylece bu adım yumuşaklaşır ve lifler daha az zarar görür.

Dai ve ark. (2013) çalışmalarında, ilk başta kenevir liflerinden nanoselüloz üretmek için oksidasyon/ultrasonlaştırma kullanmıştır. Daha sonra nanoselüloz, kenevir liflerini işlemden geçirmek için "birleştirme maddesi" ola- 
rak kullanılmıştır. Nanoselülozun boyut dağııımı nanoparçaçık izleme analizi (NTA) ile karakterize edilmiş ve nanoselülozun morfolojileri SEM ve atomik kuvvet mikroskobu (AFM) ile tanımlanmıştır. Modifiye edilmiş doğal liflerin mekanik özellikleri ve arayüzey özellikleri temel olarak incelenmiştir. SEM ve XRD, nanoselüloz modifikasyonu ile liflerin gerilme dayanımı artış mekanizmasını ortaya çıkarmak için yapılmıştır. XPS ve FTIR, doymamış polyesterle kaplanmış doğal liflerin yüzey özelliklerini araştırmak ve arayüz değişim mekanizmasını ve kendi kendini değiştirme mekanizmalarını ortaya çıkarmak amacıyla yapılmıştır. Sonuçlar, oksidasyon-sonikasyonla geliştirilen nanoselülozun daha geniş boyut aralığına (29-283 nm) ve ortalama boyuta (100-112 nm) sahip olduğu gösterilmiştir. Mekanik testler nanoselüloz modifikasyonunun doğal liflerin mekanik özelliklerini önemli ölçüde iyileştirebileceğini göstermiştir. Nanoselüloz modifiye edilmiş kenevir liflerinin modülü ve gerilmesi sırasıyla \% 36.13, \% 72.80 ve \% 67.89 artmıştır. SEM ve XRD, doğal lifler üzerinde nanoselüloz takviyesinin mekanizmasını ortaya çıkarmak için kullanılmıştır. SEM, nanoselüloz muamelesinin, liflerin yüzeyi üzerinde çizgi boyunca etkili bir nanoselüloz dağılımı ile sonuçlandığını ve işlenen kenevir liflerinin gerilme kuvvetinde önemli bir artışa yol açtığını göstermiştir. XRD analizi ayrıca, işlenmiş liflerin kristallik indeksinin \%55,17'den \%76,39'a yükseldiğini göstermiş̧tir.

Mustata ve ark. (2013)'nin çalışmasında su absorbsiyon-desorpsiyon işleminin, eğirme tipinden (kuru veya yaş) ve keten ve kenevir ipliklerinin kotonizasyon işleminden etkilenme şekli incelenmiştir. Ayrıca lif ve ipliklerin Islak ve kuru halde elektrik direnci ve oda sıcaklığında ıslanıp kurutulduktan sonra mekanik özellikleri, emilen su miktarının liflerin ve ipliklerin elektriksel direncine ve mekanik özelliklere etkisi incelenmiştir. Keten ve kenevirden kaynatılmış veya ağartıımış lif, iplik ve dokuma kumaşların higroskopik özellikleri, farklı bağıl nemlerde araştırılmıştır. Liflerin nem emiliminin doyma sınırının, kaynağa ve uygulanan ön işleme bağlı olarak değiştiği belirtilmiştir. Çalışma sonucunda, kuru eğirme ile elde edilen keten ipliklerin, kompakt yapılı yaş eğrilmiş iplikler ile karşılaştırıldığında yüksek gözeneklilik özellikleri ile daha fazla miktarda suyu absorbe ettiği gözlemlenmiştir. Keten ve kenevir iplikleri için su emme derecesinin nemlilik süresine, eğirme öncesi (kaynatma veya ağartma) liflere uygulanan bitim işlemine ve eğirme tipine (kuru veya ıslak) bağlı olduğu görülmüştür. Yaş işlemle elde edilen keten ve kenevir ipliklerinin, kaynatılmış ve ağartılmış liflerden daha fazla su absorbe ettiği gözlemlenmiştir. Yaş çekim yöntemiyle elde edilen keten ve kenevir liflerinin daha düşük su emme hızına sahip olduğu tespit edilmiştir. Keten ve kenevir ipliklerinin yaş haldeki gerilme kuvvetinde kuru haldekilere nazaran, liflerdeki su emiliminin sonucu olarak bir miktar artış gösterdiği görülmüştür. Kaynatılmış ve ağartılmış liflerden elde edilen keten iplikler için, oda sıcaklığında ıslanmanın ve sonrasında yapılan kurutmanın, kopma mukavemeti üzerinde hiçbir etkiye sahip olmadığı belirtilmiştir. Keten ve kenevir lif ve ipliklerin elektriksel direncinin, 10 dakika ıslatıldıktan sonra ıslak halde yaklaşık on kat azaldığı gözlemlenmiştir.

Richardson ve Zhang (2014)'ın çalışmasında, dokusuz yüzey kenevirin fenoliklerin mekanik özellikleri ve mikro yapısal özellikleri üzerindeki etkileri incelenmiştir. Dokusuz yüzey kenevirin eklenmesiyle fenoliklerde eğilme direnci ve modülünde önemli bir artış bulunmuştur. Darbe tokluğu büyük ölçüde iyileştirilmiştir. Bunun nedeni olarak, kenevir lifi demetlerinin boşluk gelişimi ve genişlemesi üzerinde kısıtlayıcı bir etki göstermesi olarak belirtilmiştir. Kenevir varlığının, mekanik özelliklerde iyileşmeye önemli ölçüde katkıda bulunan boşluk (kusur) sayılarını ve boyutlarını azaltma kabiliyetine sahip olduğu gözlemlenmiştir.

Stankovic ve ark. (2014) çalışmasında, kenevir liflerden üretilmiş ipliklerdeki katlama işleminin düz örme kumaşların termal ve tutum konfor özellikleri üzerindeki etkileri araştırılmıştır. Buna ek olarak üretilen kenevir örme kumaşların yapısal özellikleri, transfer özellikleri, deformasyon davranışları ve yüzey özellikleri araştırıımıştır. Elde edilen sonuçlara kenevir ipliklerinin katlanarak kullanılmasının örme kumaşların termal ve tutum özelliklerine olumlu etkilerinin olduğu, iplik yoğunluğunun artmasıyla gözeneklerin dağılımının daha düzgün olması sayesinde hava geçirgenliği ve su buharı geçirgenliğini geliştirdiği görülmüştür.

Zhang ve ark. (2014) tarafından, farklı kenevir içerikli harmanlanmış ipliklerin düzgünlük özelliklerini, mekanik özelliklerini ve yapısal özelliklerini etkileyen faktörler analiz edilmiş ve karışım oranı ile iplik mekanik özelliği arasındaki regresyon denklemi araştırıımıştır. Bu denkleme dayanarak deneyde polyester, kenevir ve pamuk lifleri kullanılarak farklı oranlarda karışım iplikler üretilmiştir. Sonuçlar incelendiğinde, iplikte kenevir lifi oranı arttıkça kenevir karışımlı ipliğin düzgünsüzlüğünün arttığı gözlemlenmiştir. Aynı zamanda kenevir lifi, sertliğinin yanı sıra, polyester ve pamuktan daha fazla lif uzunluğuna, daha büyük başlangıç modülüne, düzensiz lif kesitine ve daha büyük yüzey sürtünmesine sahip olduğundan iplik içindeki dağılımı içerikten büyük ölçüde etkilenmiştir. Kenevir lifinin mekanik özelliklerinin iplikteki dağılımından etkilendiği, pürüzsüz yüzeyleri ve düşük tutunma kuvveti nedeniyle, gerildiğinde yüksek mukavemete sahip olmalarına rağmen, birbirlerinden kaymalarının kolay olduğu görülmüştür. Kenevir lifinin, polyester ve pamuk ile belirli oranlarda karıştırıldığında, büküm etkisi altında tekrar yapışkan kuvvetinin arttığı da gözlemlenmiştir. 
Seki ve ark. (2017), selüloz esaslı liflerin takviye malzemesi olarak kullanılabilirliğini araştırmak ve geliştirmek amacıyla kompozit malzemesi olarak kullanılan bitkisel lifleri modifiye ederek fiziksel ve kimyasal özelliklerini incelemişlerdir. Yapılan çalışmalar kapsamında kompozit malzemesi olarak yaygın olarak kullanılan bitkisel liflerden keten, jüt, muz, kenevir, sisal ve hindistan cevizi liflerinin alkaliyle modifikasyonu yapılmış, liflerin içerikleri analiz edilmiş ve kimyasal FTIR, morfolojik özellikleri ise SEM ve floresan mikroskop ile incelenmiştir. Çalışmada elde edilen bulgular incelendiğinde, alkali işlem sonucunda lif yüzeyinde temizleme etkisi meydana geldiği, lifteki selülozik olmayan bileşenlerin azaldığı, lif içeriğinde meydana gelen değişime bağlı olarak verilen floresan rengin değiştiği ve lif yüzeyinin pürüzlü hale geldiği belirlenmiştir.

Paulitz ve ark. (2017)'nin çalışmasında, organik olarak yetiştirilen kenevirden elde edilen liyosel liflerinden üretilen yeni kumaşların üretimi için, entegre bir işlem zincirinin geliştirilmesine odaklanan ulusal ağ projesinin sonuçları incelenmiştir. Tüm işlem hattı, kenevir ekiminden, makine destekli hasattan ve otomatik soymadan başlayarak, kenevir şeritlerini saplardan ayırmaya; iplik üretimine, boyanmış ve bitmiş kumaşlara kadar yaş iplik eğirme ile başlanan süreç çalışmaları kapsamında kurulmuştur. Üretilen lifler, geleneksel kâğıt hamurundan yapılan yaygın liyosel lifleri gibi incelik, gerilme mukavemeti, uzama ve elastikiyet bakımından benzer özellikler göstermektedir. Proje konsorsiyumu, organik olarak yetiştirilen kenevirin hasat edilmesi ve entegre işlenmesi için yenilikçi süreç ve makineler geliştirmiştir. Kenevir bast şeritleri mekanik olarak soyulmuş kenevir kabuğundan üretilmiştir. Kenevirin odunsu parçalarının, yenilikçi kompozit malzemelere dönüştürülebileceği belirtilmiştir.

Antony ve ark. (2018) çalışmalarında, kenevir ipliklerinin mukavemet özelliklerini deneysel, analitik ve sayısal analizlerle incelemişlerdir. İlk olarak, numuneler doğrudan tafta ve sintine örgüdeki dokuma kumaşlardan ayrılan çözgü ve atkı iplikleri ile hazırlanmış ve kıvrılmış ipliğin mekanik özelliklerini karakterize etmek için çekme testleri yapılmıştır. Kenevir lifi ipliklerinin çekme yükü altında mekanik davranışlarını tahmin etmek için analitik analiz yapılmıştır. Deneysel çekme testleri farklı iplik oryantasyon açılarında yapılmıştır. Olasılık yasasına dayanarak, lif kıvrımını, elastikiyetini ve hasar olaylarını dikkate alarak matematiksel iplik davranış modeli önerilmiştir. Her çözgü ve atkı ipliğinin 3 boyutlu yeniden yapılandırılmış CAD görüntüsü ve mekanik davranışlarının sayısal simülasyonları gerçekleştirilmiştir. Simpleks ters optimizasyon yaklaşımı, kenevir ipliğinin malzeme özelliklerini optimize etmek için sayısal analizde birleştirilmiş, ipliklerin mekanik özelliklerini sayısal olarak optimize etmek için bir ters optimizasyon yaklaşımı uyarlanmıştır.
Önerilen model, farklı yönlerdeki ipliklerin çekme yüklerinde de doğrulanmıştır. Önerilen yöntemin, daha sonraki çalışmalarda kumaş davranışını karakterize etmek için kullanılabileceği belirtilmiştir.

\section{SONUÇ}

Günümüzde araştırmacılar kenevir üzerine yaptıkları çalışmalarda, hem kenevir bitkisinin özelliklerine göre değerlendirilmesini hem de yeni üretim metotları geliştirmeyi amaç haline getirmişlerdir. Çünkü kenevir liflerinin, pamuk ve benzeri hammaddelerle karıştırıldığında daha dayanıklı iplikler üretilmesine imkân sağladığı ve birim alandaki verim eldesinin yüksek olduğunu gözlemlemişlerdir. Bu sebeple kenevir lifi, sentetik lifler, cam lifleri ve birçok life karşı rakip konumdadır. Hatta kenevir lifinin kullanım alanlarında cam lifinden daha hafif olması, özellikle ısı ve ses izolasyonunda kenevire öncelik kazandırmaktadır. Sentetik liflerle benzer yapı ve kesite sahip olan kenevirin, dayanıklılık ve stabilite açısından sentetiklerle kıyaslanabilirliği bulunmaktadır. Bu sebeple kenevir lif ve iplik üretiminde sentetikler gibi daha basit ve seri üretim metotları geliştirilerek kenevirin daha yaygın ve kullanılabilir hale getirilmesi sağlanmalıdır. Bu sayede yeni pazarlar ve istihdam alanlarının önünün açılmasına olanak verilmiş olacaktır. Kenevir lifinin sahip olduğu üstün ekolojik özellikleri sebebiyle organik tekstil üretim potansiyelinin olması ve tekstil performans özelliklerinin iyi olmasından dolayı kenevir ürünlerinin üretim-tüketim bandında önümüzdeki yıllarda ciddi artış olması beklenmektedir. Ülkemizde de iklim ve toprak şartlarının uygunluğu sebebiyle yetiştirilebilen kenevir bitkisinin uygulama alanlarının geliştirilmesinin ülke ekonomisine ve istihdama büyük katkı sağlayacağı ön görülmektedir. Birçok endüstri sektörünün hammaddesi olan kenevir lifi tekstil endüstrisinde de ayrıcalığa sahiptir.

\section{KAYNAKLAR}

Acar, M., Dönmez, A. (2016). Kenevire Farklı Bir Bakış. 2. Ulusal Biyoyakıtlar Sempozyumu Bildiriler Kitabı, 27-30 Eylül, 2016, Samsun, Türkiye, 265-270.

Al-Oqla, F. M., \& Sapuan, S. M. (2014). Natural fiber reinforced polymer composites in industrial applications: feasibility of date palm fibers for sustainable automotive industry. Journal of Cleaner Production, 66, 347-354.

Amaducci, S. (2003). HEMP-SYS. Journal of Industrial Hemp 8(2): 79-83.

Amaducci, S., Gusovius, H.J. (2010). Industrial Application of Natural Fibres: Properties and Technical Application, Chapter II Hemp - Cultivation, Extraction and Processing, Edited by Jöhn Mössig, Wiley Series in Renewable Resources, United Kingdom, 109-135.

Antony, S., Cherouat, A., Montay, G. (2018). Experimental, analytical and numerical analysis to investigate the tensile behaviour of hemp fibre yarns. Composite Structures 22: 482-490. 
Ariyakuare, K. (2010). The Development of New Mixed Fiber from Waste Cocoon and Other Plant Fibers, The 2nd RMUTP International Conference: Green Technology and Productivity, Bangkonk, Thailand, 369-375.

Awwad, E., Mabsout, M., Hamad, B., Farran, M. T., \& Khatib, $H$. (2012). Studies on fiber-reinforced concrete using industrial hemp fibers. Construction and Building Materials, 35, 710-717.

Aytaç, S. (2018). Endüstriyel Kenevir Gerçeği ve Ülkemizdeki Durum, Karadeniz Tarımsal Araştırma Enstitüsü Müdürlüğü Endüstriyel Kenevir Gerçeği Paneli, 2-3 Mayıs, 2018, Samsun.

Aziz, S.H., Ansell, M.P. (2004). Optimising the Properties of Green Composites, Green composites: Polymer Composites and the Environment, Edited by Caroline Baillie, Woodhead Publishing Series in Composites Science and Engineering, Cambridge, United Kingdom, 154-180.

Başer, İ., (2002). Doğal Lifler. Lif Bilgisi 2. Bölüm, Marmara Üniversitesi Döner Sermaye İşletmesi Teknik Eğitim Fakültesi Matbaa Birimi, 53-54.

Bengtsson, E. (2009). Obtaining High Quality Textile Fibre from Industrial Hemp Through Organic Cultivation. Bachelor Project at the LTJ Faculty, The Horticultural Programme 2009-03, Alnarp, Sweden, 40.

Célino, A., Fréour, S., Jacquemin, F., Casari, P. (2014). The hygroscopic behavior of plant fibers: a review. Frontiers in Chemistry 24: 1-12.

Cierpucha, W., Kozlowski, R., Mankowski, J., Wasko, J., Mankowski, T. (2004). Applicability of flax and hemp as raw materials for production of cotton-like fibres and blended yarns in Poland. FIBRES \& TEXTILES in Eastern Europe 3(47): 12-18.

Dai, D., Fan, M., Collins, P. (2013). Fabrication of nanocelluloses from hemp fibers and their application for the reinforcement of hemp fibers. Industrial Crops and Products 44: 192-199.

Delaney, T., Madigan, T. (2014). Beyond Sustainability: a Thriving Environment. Mcfarland\&Company, USA.

Dreyer, J., Müssig, J., Koschke, N., Ibenthal, W.D., Harig, H. (2002). Comparison of enzymatically separated hemp and nettle fibre to chemically separated and steam exploded hemp fibre. Journal of Industrial Hemp 7(1): 43-59.

European Industrial Hemp Association(EIHA), URL:http://eiha.org/about/, (Erişim Tarihi: Eylül, 15, 2019).

Fuqua, M.A., Huo, S., Ulven, A.C., (2012). Natural fiber reinforced composites. Polymer Reviews 52(3): 259-320.

Gedik, G., Avinç, O.O., Yavaş, A. (2010). Kenevir lifinin özellikleri ve tekstil endüstrisinde kullanımıyla sağladığı avantajlar. Tekstil Teknolojileri Elektronik Dergisi 4(3): 39-48.

Harmancıoğlu, M., Yazıcıoğlu, G. (1979). Bitkisel Lifler. Ege Üniversitesi Dergisi, Yayın No:33, 336.

Hautala, M., Pasila, A., Pirila, J. (2004). Use of hemp and flax in composite manufacture: a search for new production methods. Composites Part a Applied Science and Manufacturing 35: 11-16.

Herer, J. (1993). Die Wiederentdeckung Der Nutz-Pflanze. Zweitausendeins Verlag, Frankfurt Am Main, Germany, 325.

Hess, K.P. (1954). Textile Fibers and Their Use, J.B. Lippincott Company, Chapter 50, USA, 547.

Hwang, M.S, Ji, D.S. (2012). The effects of yarn number and liquid ammonia treatment on the physical properties of hemp woven fabrics. Fibers and Polymers 13(10): 13351340.

John, M.J., Thomas, S. (2008). Biofibers and biocomposites. Carbohydrate Polymers 71: 343-364.

Karus, M., Vogt, D. (2004). European hemp industry: cultivation, processing and product lines. Euphytica 140: 7-12.

Keller, A. Leupin, M., Mediavilla, V., Wintermantel, E. (2001). Influence of the growth stage of industrial hemp on chemical and physical properties of the fibres. Industrial Crops and Products 13(1): 35-48.

Kostic, M., Pejic, B., Skundric, P. (2008). Quality of chemically modified hemp fibers. Bioresource Technology 99: 94-99.

Kozlowski, R., Mieleniak, B., Muzyczek, M., Kubacki, A. (2002). Flexible fire barriers based on natural nonwoven textiles. Fire And Materials 26: 243-246.

Marrot, L., Lefeuvre, A., Pontoire, B., Bourmaud, A., Baley, C. (2013). Analysis of the hemp fiber mechanical properties and their scattering (fedora 17). Industrial Crops and Products 51: 317-327.

Mediavilla, V., Leupin, M., Keller, A. (2001). Influence of growth stage of industrial hemp on the yield formation in relation to certain fibre quality traits. Industrial Crops and Products 13(1): 49-56.

Merdan, N., Koçak, D., Acar, K. (2012). Kenevir liflerinin konvansiyonel ve mikrodalga yöntemine göre maleik anhidrit ile yüzey modifikasyonu. İstanbul Ticaret Üniversitesi Fen Bilimleri Dergisi 11(22): 71-78.

Miranda, D.D. (2011). An Evaluation of Hemp Fiber for Furnishing Applications. In partial fulfillment of the requirements, The Degree of Master of Science Thesis, Colorado State University, May 2011, Colorado, USA.

Mustata, A., Mustata, Fstc. (2013). Moisture absorption and desorption in flax and hemp fibres and yarns. FIBRES \& TEXTILES in Eastern Europe 21, 3(99): 26-30.

Müssing, J., Karus, M., Frank, R.R. (2005). Bast and Other Plant Fibres, Chapter 1- Hemp, Woodhead Publishing, Edited by Robert R. Franck, United Kingdom, 176-200.

Mwaikambo, L.Y. (2006). Review of the history, properties and application of plant fibres. African Journal of Science and Technology (AJST) Science and Engineering Series 7(2): 120-133.

Najjar, S. S., Sadek, S., \& Taha, H. (2014). Use of hemp fibers in sustainable compacted clay systems. In Geo-Congress 2014: Geo-characterization and Modeling for Sustainability (pp. 1415-1424).

Orta Anadolu Kalkınma Ajansı. (2019). Kenevir Yetiştiriciliği. http://www.oran.org.tr/images/dosyalar/20190318134910_0.pdf, (Erişim Tarihi: Mayıs, 22, 2019).

Ouajai, S., Shanks, R.A., Hodzic, A. (2004). Morphological and grafting modifications of natural cellulose fibers. Journal of Applied Polymer Science 94: 2456-2465.

Özdemir, S., Tekoğlu, O. (2013). Ekolojik tekstil ürünlerinde kullanılan hammaddeler. Akdeniz Sanat Dergisi 4(8): $27-$ 30.

Özşeker, P.E., Dip, A., Dağlığlu, N., Gülmen, M.K. (2017). Sentetik kannabinoidler: yeni nesil esrar. Türk Aile Hekimleri Dergisi 21(1): 34-40.

Paulitz, J., Sigmund, I., Kosan, B., Meister, F. (2017). Lyocell fibers for textile processing derived from organically grown hemp. Procedia Engineering 200: 260-268. 
Prade, T., Svensson, S., Andersson, A., Mattsson, J.E. (2011). Biomass and energy yield of industrial hemp grown for biogas and solid fuel. Biomass Bioenergy 35(7): 3040-3049.

Prade, T., Svensson, S., Mattsson, J.E. (2012). Energy balances for biogas and solid biofuel production from industrial hemp. Biomass Bioenergy 40: 36-52.

Qiguang, LBDJF., Dongcheng, W. (2011). Development of hemp cotton combed vortex yarn. Cotton Textile Techno$\log y 11$.

Reddy, N., Yang, Y.Q. (2005). Biofibers from agricultural by products for industrial applications. Trends Biotechnology 23(1): 22-27.

Richardson, M., Zhang Z. (2001). Nonwoven hemp reinforced composites. Reinforced Plastics 45: 40-44.

Salentijn, E.M.J., Zhang, Q., Amaducci, S.,Yang, M., Trindade, L.M. (2014). New developments in fiber hemp (cannabissativa I.) breeding. Industrial Crops and Products 68: 32 41.

Satya, P., Maiti, R. (2013). Biofuel Crops-Production, Physiology and Genetics, Part III- Bast and Leaf Fibre Crops: Kenaf, Hemp, Jute, Agave, Etc., Edited by Emma Mccann, CAB International, Wallingford, United Kingdom, 292-311.

Seki, Y., Selli, F., Şen, K., Erdoğan, Ü.H. (2017). Kompozit malzeme üretiminde kullanılacak bitkisel liflerin alkali modifikasyonu sonrası morfolojik ve kimyasal yapılarındaki değişimin incelenmesi. Tekstil ve Mühendis 24(108): 222 232.

Shahzad, A. (2011). Hemp fiber and its composites - a review. Journal of Composite Materials 46(8), 973-986.

Stankovic, S.B. (2008). Static lateral compression of hemp/filament hybrid yarn knitted fabrics. Fibers and Polymers 9(2): 187-193.
Stankovic, S.B., Bizjak, M. (2014). Effect of yarn folding on comfort properties of hemp knitted fabrics. Clothing and Textiles Research Journal 32(3): 202-2014.

Stankovic, S.B., Popovic, D., Poparic, G.B. (2008). Thermal properties of textile fabrics made of natural and regenerated cellulose fibers. Polymer Testing 27: 41-48.

Tserki, V., Zafeiropoulos, N.E., Simon, F., Panayiotou, C.A. (2005). A study of the effect of acetylation and propionylation surface treatments on natural fibers. Composites Part an Applied Science and Manufacturing 36: 1110-1118.

Turunen, L., Van Der Werf, H.M.G. (2007). The production chain of hemp and flax textile yarn and its environmental impacts. Journal of Industrial Hemp 12(2): 43-66.

Ulaş, E. (2018). Gerçek Köye Dönüş Projesi: Kenevir. Hatice Bahtiyar (Editör), Hiperlink Yayınları, İstanbul.

Zhang, H., Zhang, J., Gao, Y. (2014). Study on the relationship between blending ratio and performance of hemp/polyester yarn. Journal of Natural Fibers 11(2): 136-143.

Zhang, L.L., Zhu, R.Y., Chen, J.Y., Chen, J.M., Feng, X.X. (2008). Seawater-retting treatment of hemp and characterization of bacterial strains involved in the retting process. Process Biochemistry 43: 1195-1201.

Zhihai, S. (2011). Spinning of cotton hemp bamboo fiber blended yarn. Cotton Textile Technology 11.

Zimniewska, M., Wladyka-Przybylak, M., Mankowski, J. (2011). Cellulose Fibers: Bio- and Nano-Polymer Composites-Green Chemistry and Technology. Part I- Cellulosic Bast Fibers, Their Structure and Properties Suitable for Composite Applications, Springer-Verlag, 97-121. 